\title{
Desafio diagnóstico: Nefrite lúpica em pacientes do sexo masculino- Relato de Caso
}

\author{
Andrade, K.; Andrade, E.J.; Demarco, F.R.; Giovanella, L.; Bastos, F.N.; \\ Bandeira, M.P.W.; Paniz, G.; \\ Apresentador: Karina de Andrade
}

\section{Resumo}

Introdução: O lúpus eritematoso sistêmico (LES) é uma doença inflamatória crônica, de natureza autoimune, que pode afetar múltiplos sistemas, sendo a nefrite lúpica a principal causa de morbimortalidade. Pelos critérios do Colégio Americano de Reumatologia, a nefrite lúpica é definida pela presença de proteinúria persistente ou maior que 3+ e/ou pela cilindrúria. O LES é classicamente apresentado em mulheres em idade fértil por ter uma relação de sexo de 9:1. Entretanto, o LES no sexo masculino tem uma maior gravidade e maior mortalidade devido à pior progressão da doença renal e hematológica. Paciente do sexo masculino, 55 anos, procurou a emergência do IC- FUC com queixa de astenia e dispneia. Realizados exames laboratoriais foi evidenciado proteinúria de 1,2g e IPC $>0,3$ sugerindo síndrome nefrótica. Paciente transferido para a enfermaria de Nefrologia da Santa Casa de Misericórdia de Porto Alegre onde referiu que há 60 dias iniciou com edema em MsIs, aumento de $12 \mathrm{~kg}$ um mês, a dispneia progressiva e oligúria. HMP de HAS de difícil controle há 12 anos e IC diastólica. Paciente evoluiu com piora do quadro de dispneia e aumento da proteinúria $(14,22)$ e IPC $=7,85$. Realizada ecografia renal evidenciando perda do padrão córticomedular. No Rx de tórax se evidenciou derrame pleural à E. Impressão de síndrome nefrótica/GNRP indicando a necessidade de biópsia renal. Iniciou com sinais de uremia e foi submetido há hemodiálise e novos laboratoriais: FAN nuclear homogêneo 1: 2.560, C3: 52, C4: 14, Anti-DNA reagente 1: 280, linfócitos: 471 . $\mathrm{Na} b x$ renal se evidenciou GN membranoproliferativa com depósitos de imunocomplexos e dois crescentes. Confirmado o diagnóstico de LES, de acordo com os critérios diagnósticos, paciente com doença ativa e nefrite lúpica. Iniciado tratamento com hidroxicloroquina, pulsoterapia de ciclofosfamida, prednisona e encaminhado para acompanhamento no ambulatório de reumatologia. De a acordo com a literatura, homens com LES apresentam uma doença mais complexa, com mais internações e com maior duração, sugerindo uma maior morbidade em relação as mulheres. Além disso, a Nefrite Lúpica tende a se apresentar com maior frequência e ter uma evolução mais rápida, com consequente piora no seu prognóstico. Por isso, o LES deve ser considerado no diagnóstico diferencial em pacientes homens com sinais e sintomas típicos, para se realizar um diagnóstico mais precoce com uma maior chance de impacto positivo no seu prognóstico.

\section{Referência:}

Andrade, K.; Andrade, E.J.; Demarco, F.R.; Giovanella, L.; Bastos, F.N.; Bandeira, M.P.W.; Paniz, G.; Desafio diagnóstico: Nefrite lúpica em pacientes do sexo masculino- Relato de Caso. In: II Congresso Brasileiro de Medicina Hospitalar - II CBMH [= Blucher Medical Proceedings, vol.1, num.5] São Paulo: Editora Blucher, 2014. p.96

DOI 10.5151/medpro-II-cbmh-095 